\section{Nastamonu Eğitim Dergisi Kastamonu Education Journal}

Temmuz 2019 Cilt:27 Sayı:4

kefdergi.kastamonu.edu.tr
Başvuru Tarihi/Received: 05.06.2018

Kabul Tarihi/Accepted: 30.09.2018

DOI: 10.24106/kefdergi.3131

\title{
Özel Okul ve Devlet Okulunda Görev Yapmış Sınıf Öğretmenlerinin Öğretim Programlarını Uygulamada Karşılaştıkları Farklılıklar
}

\section{Differences Encountered by Classroom Teachers Who Worked at Private and State Schools in the Implementation of the Curriculum}

\section{Öz}

\author{
Serkan ÜNSAL ${ }^{1}$ Abdullah ÇETIN²
}

Bu araştırmanın amacı devlet ve özel okulların her ikisinde de görev yapmış sınıf öğretmenlerinin deneyimleri bağlamında, özel okul ve devlet okullarında öğretim programlarını uygulama açısından ne gibi farklılıkların olduğunu ortaya çıkarmaktır. Araştırma nitel araştırma desenlerinden olgubilim deseninde yürütülmüştür. Araştrrma verileri yarı yapılandırımış görüşme formuyla toplanmıştı. Veriler içerik analizi yöntemiyle analiz edilmiştir. Araştırmanın sonucunda özel okulda çalışan öğretmenlerin öğretim programının içeriğine bağlı kaldıkları, ek kaynak aldırdıkları ve bazı derslere daha fazla ağırlık verdikleri görülmüştür. Özel okullarda yönetimin desteği, öğrencilerin hazırbulunuşluğu ve okulun fiziki donanımın iyi olması nedeniyle öğretim programını uygulamada kullanılan yöntem ve teknik bakımından farkın olduğu, ölçme ve değerlendirme bakımından deneme sınavlarıyla öğrencileri değerlendirme dışında farkın olmadığı sonucuna ulaşılmıştır.

Anahtar Kelimeler: öğretim programı, özel okul, sınıf öğretmeni

\section{Abstract}

This research concentrates on the differences in implementing curriculum in private and state schools within the context of the experiences of private school classroom teachers who worked at state schools. This qualitative research has a phenomenological design. Content analysis was used during data analysis. Research results have revealed that classroom teachers working at private schools stick to the content of the program, support the use of resource books and attach much more significance to some of the lessons. Due to the support of the management in private schools, the readiness of the students and physical equipment of the school, a difference has been determined in terms of the methods and techniques used in the implementation process of the curriculum. There has been no difference across measurement and evaluation except for testing students with pilot tests.

Keywords: classroom teacher, private school, curriculum 


\section{Extended Abstract}

This research concentrates on the differences in implementing curriculum in private and state schools within the context of the experiences of private school classroom teachers who worked at state schools. In service of this goal, answers to the following questions have been sought:

1- Do private schools differ from state schools in terms of content selection and implementation?

2- Do private schools differ from state schools in terms of the selection and use of methods and techniques?

3- Do private schools differ from state schools in terms of the selection and use of measurement and evaluation techniques?

4- What are the effects of the parents, students, physical equipment and management of the school on the difference in the implementation of the curriculum?

Method : Examining the views of the private school classroom teachers who worked at state schools on the implementation of the curriculum, this qualitative research has a phenomenological design. The research data have been collected through a semi-structured interview form developed by the researchers and consisting of 2 sections. Content analysis was used during data analysis. During the preparation process of the form, the views of the experts have been taken under consideration in order to ensure the validity and reliability. Besides, detailed information concerning the research process have been presented, purposeful sample method has been used, direct citations have been included, the findings have been reported and written with a clear and proper language for the readers, research documents have been kept by the researcher (Yıldırım and Şimşek, 2013, Lincoln and Guba, 1985, Miles and Huberman, 1994).

Findings: Research results have revealed that teachers have common ideas regarding the similarity of the content of the private and public schools' curriculum. Six of the teachers have noted the presence of resource books support in private schools. One of the teachers has indicated that the content is actively implemented due to the equipment support. Likewise, one teacher has noted that private schools attach much more significance to some of the lessons.

Six teachers have stated the differences in the implementation of the curriculum in private and state schools depending on the use of methods and techniques, while 2 of whom have pointed out the opposite. Those who emphasized the difference have clarified the reasons of these differences such as using more student-centered methods and techniques and utilizing a variety of methods and techniques.

Three of the teachers have stated that private and state schools do not differ across the selection and use of measurement and evaluation techniques; whereas three of them have implied the emergence of the difference. The teachers who think that the measurement and evaluation techniques applied in private schools differ from those of the state schools have noted the extra use of project assignments, peer evaluation and pilot tests.

This research has suggested the impact of administration, school, parents and students upon the implementation of the curriculum in private schools. The influence of administration has been interpreted by three teachers as the support provided during the activities and by five teachers as offering opportunities to perform activities. Within the scope of the school effect, all of the teachers have signified that the implementation of the curriculum is more effective compared to the state schools thanks to the potentials in private schools. The teachers have also emphasized that self-confidence and readiness level of the students have a significant effect on the implementation of the curriculum.

Result and Discussion : Bümen et al. (2014) has considered the reason for which classroom teachers who worked at private schools stick to the content of the program as the concept of commitment to the curriculum defined as the implementation of the designed program by the teacher / stakeholders faithfully. It may also be due to teachers' concern for being inspected by The Ministry of Education (MoE, 2016; Memduhoğlu, 2008; Özdemir and Tüysüz, 2017). Another reason for the fact that teachers working at private schools are loyal to the content of the curriculum may arise from parents' academic achievement expectations (Çelikten, 2010). The results have also shown that teachers are in an effort to meet parents' expectation by giving more importance to some lessons such as English. Upon analyzing the literature review, foreign language teaching is among the reasons for parents to prefer private schools (Açıkalın, 1989; Çelikten, Parlar, 2006).

The study reviews the difference between private and state schools in terms of the implementation of the teaching principles and methods. This difference may be due to the differences of the education environment in both types of school. As indicated by Pehlivan (2004), the equipment and physical conditions of a school play a significant role in affecting the implementation of the curriculum.

Private school classroom teachers who worked at state schools have been identified to use traditional measurement and evaluation techniques such as observation, test, and exams. This may result from the reasons that teachers have insufficient knowledge and skills regarding alternative measurement and assessment tools and their implementation (Anıl \& Acar, 2007; Gelbal and Kelecioğlu 2007; Okur and Azar, 2011), and they cannot change the culture they have about measurement and assessment (Cansız Aktaş, 2008). Another result of the research depicts that the implementation of the curriculum in private schools is affected by administrators, the physical infrastructure of the school, parents and students. Similar results have emerged in the studies conducted by Bay, et al., 2017; Bümen, et al., 2014).

| Kastamonu Eğitim Dergisi, 27(4), 2019| 


\section{Giriş}

Eğitim kavramı genel anlamda formal (biçimsel) ve informal (biçimsel olmayan) olmak üzere iki kategoride değerlendirilir. Formel eğitimi informal eğitimden ayıran bir çok özellik olmakla birlikte temel fark bir plan dahilinde ve bir amaca dönük olarak gerçekleşmesidir. Formal eğitimin bir amaç doğrultusunda planlı şekilde yapılması ise eğitim ve öğretim programları sayesinde mümkün olabilir. Öğretim programını Görgen (2012), eğitim programı içinde ağırlığı fazla olan, bir dersin öğretimi ile ilgili tüm etkinlikleri kapsayan bir plan olarak tanımlarken, Küçükahmet (1997) bilgi ve becerilerin eğitim programı amaçları doğrultusunda planlı bir şekilde kazandırılması olarak tanımlamaktadır. Demirel (2012) ise öğretim programını, okul içinde okul dışında kavramlarına vurgu yaparak bir dersin öğretimiyle ilgili etkinliklerin tamamının yer aldığı plan olarak tanımlamıştır. Öğretim programlarının hazırlanması ülkelerin eğitim sistemlerine bağlı olarak değişmektedir. Türkiye'de öğretim programlarının hazırlanması ve onaylanması süreci Milli Eğitim Bakanlığına bağlı Talim Terbiye Kurulu Başkanlığı tarafindan yürütülmektedir (Yaşaroğlu ve Manav, 2015).

Öğretim programının uygulayıcıları okullarda öğretmenlerdir. Bu yüzden programın amacına uygun bir şekilde uygulanması, yürütülmesi konusunda öğretmenlere büyük görevler düşmektedir (Bütün ve Gültepe, 2016). Öğretmenlerin öğretim programına karşı tutumları, hazırlanan öğretim programları uygulamalarını etkilemekte, öğretim programları her okulda aynı şekilde uygulanmamaktadır (Bay, Kahramanoğlu, Döş ve Özpolat, 2017; Bümen, Çakar ve Yıldız, 2014; Ercan, 2011; Kara, Karakoç, Yıldırım ve Bay, 2017). Diğer bir ifade ile programın uygulayıcısı olan öğretmenlerin MEB'in belirlediği öğretim programından farklı olarak pek çok uygulamaya yöneldikleri görülmektedir (Acar, 2007; Aykaç ve Ulubey 2012; Öztürk Akar, 2005). Öğretmenlerin öğretim programının uygulamasında farklııılara gitmesinin sebepleri; öğretmenlerin programı uygulama konusunda yeterli donanıma sahip olamaması, sınıfların kalabalık olması,öğretmenlerin yeni rollerini yeteri kadar benimseyememesi, okulun fiziki durumu, öğretmenin bireysel karar ve tercihlerini öğretime yansıtması şeklinde olabilir (Acar, 2007; Aydemir, 2011; Aykaç ve Ulubey, 2012; Bal, 2008; Çobanoğlu, 2011; Fettahoğlu, 2011; Öztürk, 2012; Öztürk Akar, 2005; Tekbıyık ve Akdeniz, 2008; Yaman, 2009). Bunun yanında okullardaki imkânların, öğrencilerin sahip oldukları özeliklerinde öğretmenlerin öğretim programı uygulanmasına yansıyarak, öğretmenlerin uygulamada değişiklik yapmalarına sebep olan diğer faktörlerdir (Gwimbi ve Monk 2003; Han, 2013). Özel okullar imkanları ve öğrencinin hazırbulunuşluğu bakımından devlet okullarına göre daha avantajlı olarak görülebilir.

Özel okullar gelir ve giderleri gerçek veya tüzel kişilerce karşılanan, sahipleri gerçek kişiler veya yardım kuruluşları olabilen, belli bir ücret karşılığında anaokulundan üniversiteye kadar eğitim-öğretim hizmeti veren, bu süreçlerde denetimi MEB tarafindan yapılan kurumlardır (MEB, 2016; Memduhoğlu, 2008; Uygun, 2003). Özel okullar tüm faaliyetlerini 5580 sayılı Öğretim Kurumları Kanunu hükümlerine göre yürüten özel öğretim kurumlarıdır (Özdemir ve Tüysüz, 2017; MEB, 2016)Yaklaşık yüz yıllık bir tarihi olan özel okullara (Açıkalın, 1989) hergeçen gün talep/ ilgi artmakta ve bu doğrultuda ise özel okullar sayıları artmaktadır (Özdemir ve Tüysüz, 2017). Özel okullara talebin olmasının sebepleri ise okulların fiziki olarak yüksek standartlara sahip olması, eğitim alanında uluslar arası yaklaşımları uygulamaları, nitelikli eğitim vermeleri, teknolojiyi takip etmeleri, ulusal ve uluslarası sınavlarda göstermiş oldukları başarılar, yabancı dil eğitiminde başarıları, sosyal ve sportif etkinliklerin yoğun olması, teknoloji ile eğitim süreçlerini entegre etmesi, etkin rehberlik çalışmaları yapmaları, veli işbirliğinin sağlanması, eğitim kadrosunun akademik olarak deneyimli ve donanımlı olması, özgün bir program uygulaması şeklinde sıralanabilir (Açıkalın, 1989; Çelikten, 2010; Çobanoğlu, 2011; Dikbaş, 2008; Erdoğan, 2005; Eyüpoğlu, 2002; Subaşı ve Dinler, 2003; Mermertaş, 2014; Parlar, 2006). Özel okulların bahsedilen niteliklere sahip olmasının nedeni rekabet ortamın getirdiği koşullara bağıı olarak, veli ve öğrencilerin beklentilerini karşılamak için, okulun fiziki alt yapısını güçlendirme, nitelikli öğretmenleri çalıştırma yoluna gitmeleridir (Ensari, 2002). Aynı zamanda özel okullar, teknoloji ile eğitim süreçlerini entegre ederek öğrenme ortamlarında öğrenci ve velilerine çeşitli araştırma, inceleme ve değerlendirme yapma imkânı sunarak kaliteli eğitim ve öğretim beklentilerini karşılamaya çalışmaktadırlar (Subaşı ve Dinler, 2003).

Velilerin özel okulları tercih etme nedenlerinin başında özel okullarda okuyan öğrencilerin akademik başarısının devlet okullarına göre daha yüksek olduğuna yönelik veli algısı (Akın, Şimşek ve Erdem, 2007) ve özel okulların ulusal ve uluslararası sınavlarda devlet okullarına göre daha başarılı olması (Berberoğlu ve Kalender, 2005; Uysal, 2017) gelmektedir. Özel okulların devlet okullarına göre daha başarılı olması veya veliler tarafindan başarılı algılanmasında birçok faktör rol oynayabilir. Üzerinde durulması gereken önemli faktör nitelikli bir eğitim öğretimi için vazgeçilmez koşulu olan öğretim programları ve öğretim programlarının nasıl uygulandığıdır. Öğretmenlerin sınıftaki öğretim uygulamalarında kendi tercihlerini yansıttkkları (Öztürk, 2012), düşünüldüğünde bu tercihlerinde özel okulların özelliğinin ne kadar etkili olduğu sorusu araştırmacılar tarafindan araştrılmaya değer bulunmuştur. Bu açıdan araşttrmanın problem cümlesi; Devlet ve özel okullarının her ikisinde de çalışmış sınıf öğretmenlerinin deneyimleri bağlamında, özel okul ve devlet okullarının ilköğretim programını uygulama açısından ne gibi farklar vardır? şeklinde oluşturulmuştur. Bu kapsamda 
aşağıdaki sorulara cevaplar aranmıştir.

1. İçeriğin seçimi ve işlenişi bakımından özel okul devlet okulundan farklılaşmakta mıdır?

2. Yöntem ve teknik seçimi ve kullanımı bakımından özel okul devlet okulundan farklılaşmakta mıdır?

3. Ölçme ve değerlendirme tekniklerinin seçimi ve kullanımı bakımından özel okul devlet okullarından farklılaşmakta mıdır?

4. Öğretim programın uygulanmasında farklığın oluşmasına veli, öğrenci, okulun fiziki donanımı ve yönetiminin etkileri nelerdir?

\section{Yöntem}

Araştırmanın bu bölümünde araştırmanın deseni, çalışma grubu, verilerin toplanması ve verilerin analizine ilişkin bilgiler sunulmuştur.

\section{Araştırmanın Deseni}

Bu araştırma, devlet ve özel okullarının her ikisinde de çalışmış sınıf öğretmenlerinin her iki kurumda da uygulamaya koydukları öğretim programına ilişkin görüşlerinin derinlemesine incelendiği olgubilim deseninde nitel bir araştırmadır. Bu desenle farkında olunan ancak ayrıntılı bilgiye sahip olunmayan ya da üzerinde çok düşünmediğimiz olguya ilişkin olarak bireylerin deneyimleri, algılarını ve yönelimleri, derinlikli bir şekilde ortaya çıkartılması amaçlanır (Creswell, 2015; Patton, 2014; Yıldırım ve Şimşek, 2013). Bu araştırmada incelenen olgu öğretim programı uygulamalarıdır.

\section{Çalışma Grubu}

Olgubilim deseninde bireyler seçilirken, bireylerin olguyla ilişkili birincil kişiler olmasına dikkat edilmesi gerekmektedir (Creswell, 2015; Patton, 2014). Bu araştırma da zengin veri setine ulaşılması amaçlandığından, olguyla ilgili kişilerin seçiminde amaçlı örnekleme yönteminden ölçüt örnekleme tercih edilmiştir. (Miles ve Huberman, 1994) Bu örneklemede seçim için önemli olduğu düşünülen ölçütler belirlenmektedir (Tavşancıl ve Aslan, 2001). Bu araştırmada ölçütler; 2017-2018 eğitim-öğretim yılında bahar döneminde Kahramanmaraş’ta özel okullarda sınıf öğretmeni olarak görev yapıyor olmak, daha önce devlet okullarında görev yapmış olmak, her iki kurumda deneyim sahibi olmak, araştırmaya gönüllü katılmak şeklinde belirlenmiştir. Bu ölçütlere uyan sekiz öğretmen araştırmanın çalışma grubunu oluşturmaktadır. Katılımcı öğretmenler etik kurallarına uymak adına Ö1...Ö8 şeklinde kodlanmıştır. Çalışma grubunun özellikleri Tablo 1'de verilmiştir.

Tablo 1. Çalışma Grubunun Özellikleri

\begin{tabular}{lllll}
\hline Kod & Cinsiyet & Devlet okulunda çalışma süresi & Özel okulda çalışma süresi & Yaş \\
\hline Ö1 & Erkek & 26 & 12 & 58 \\
Ö2 & Erkek & 27 & 10 & 61 \\
Ö3 & Kadın & 26 & 5 & 51 \\
Ö4 & Erkek & 32 & 4 & 57 \\
Ö5 & Erkek & 27 & 6 & 59 \\
Ö6 & Kadın & 23 & 6 & 50 \\
Ö7 & Erkek & 32 & 5 & 57 \\
Ö8 & Kadın & 25 & 3 & 48 \\
\hline
\end{tabular}

Tablo 1 incelendiğinde erkek öğretmenlerin sayısı, kadın öğretmenlere göre daha fazladır (\% 62.5). Öğretmenlerin devlet okullarındaki çalışma süresi 25 yıl ve üzerindedir. Öğretmenlerin yaşı 50 ve üzeridir.

\section{Verilerin toplanması ve analizi}

Araştırmada veriler, araştırmacılar tarafindan geliştirilen ve iki bölümden oluşan yarı yapılandırılmış görüşme formu ile toplanmıştır. Yarı yapılandııımış görüşme formunda yer alan sekiz sorunun dördü demografik bilgileri almaya yönelik, dördü ise öğretim programını uygulamasına ilişkin görüşlerinin belirlenmesine yönelik açık uçlu sorulardan oluşturulmuştur. Görüşme formunda hazırlanma aşamaları ise; alanyazın ve araştırmanın amacına uygun olarak taslak soruların hazırlanması, hazırlanan soruların uzman görüşüne sunulması, uzman görüşleri doğrultusunda gerekli düzeltme ve değişikliklerin yapılması, ön uygulamaların yapılması ve son aşama ise görüşme formuna son şeklinin verilmesi şeklinde gerçekleşmiştir. Görüşmeler 2018 yılı Mart- Nisan ayında öğretmenlerin çalıştkları kumlarda gerçekleştirilmiştir. Bu teknik, özel bir konuda derinlemesine soru sorma ve cevap eksik veya açık değilse tekrar soru sorarak durumu daha açıklayıcı hale getirip cevapları tamamlama firsatı vermesi açısından avantajıdır (Çepni, 2007). 
Bu araştrrma da elde edilen veriler içerik analizi yöntemi ile analiz edilmiştir. İçerik analizi, toplanan verilerin derinlemesine analiz edilmesini gerektirir ve önceden var olmayan yeni temaların, kategorilerin ve boyutların ortaya çıkmasına olanak tanır (Yıldııım ve Şimşek, 2013). İçerik analiz sürecinde ise önce birbirine benzeyen nitel veriler okuyucu için anlamlı olacak şekilde tema ve kodlar oluşturulmuş, sonrasında neden- sonuç ilişkileri yakalanmaya çalışılmış, son aşamada ise yorumlanarak sonuçlandırılmıştı (Kızıltepe, 2015; Yıldırım ve Şimşek, 2013).

\section{Geçerlik ve güvenirlik}

Araştırmada geçerlik ve güvenirliği sağlamak için, görüşme formu hazırlanırken uzman görüşüne başvurulmuş, araştırmanın gerçekleştirilme aşamalarına ilişkin ayrıntılı bilgi verilmiş, amaçlı örnek kullanılmış, öğretmen görüşlerinden doğrudan alıntılara yer verilmiş, elde edilen bulgular ayrıntlı bir şekilde raporlaştırılmış ve okuyucu için anlaşılır bir dil kullanmış, araştırmaya ilişkin belgeler araştırmacı tarafindan saklanmıştır (Lincoln ve Guba, 1985; Miles ve Huberman, 1994; Yıldııım ve Şimşek, 2013). íki araştırmacı birbirinden bağımsız olarak verileri analiz ederek tema ve kodları oluşturmuş, daha sonra bu kodlar karşılaştrılarak araştırmacılar arasında belli bir fikir birliğine varılmıştı (Creswell, 2015; Yıldırım ve Şimşek, 2013).

\section{Bulgular}

Araştırmanın cevap aradığı birinci soru içeriğin seçimi ve işlenişi bakımından devlet okuluna göre özel okullarda farlılık olup olmadığının belirlenmesidir. Bu kapsamda öğretmen görüşlerinde elde edilen bulgular şekil 1 de verilmiştir.

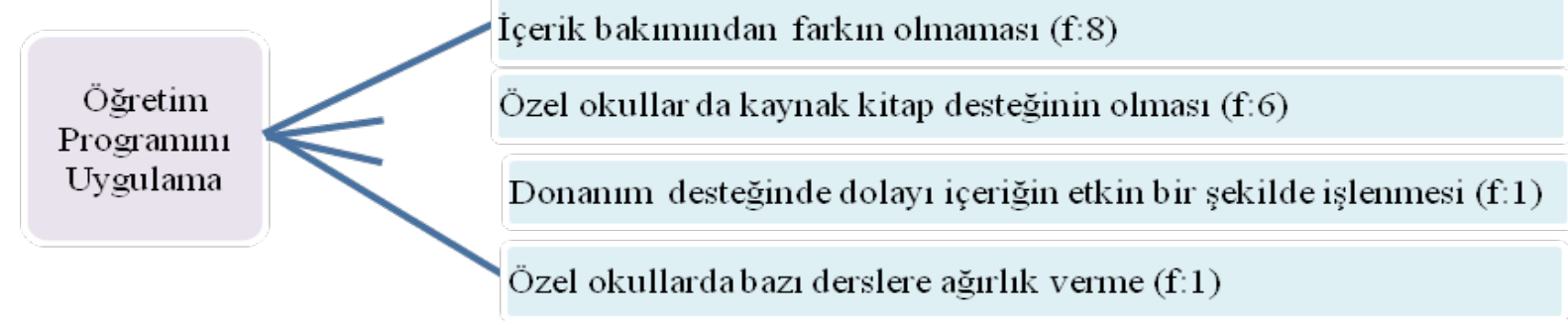

\section{Şekil 1.Öğretmenlerin içerik belirleme karşılaştıkları farklılıklar}

Katılımcı öğretmenlerin tamamı her iki okulda içeriğin aynı olduğunu, alt öğretmen özel okullarda kaynak kitap desteğin olduğunu, bir öğretmen donanım desteğinden dolayı içeriğin etkin şekilde işlendiğini, yine bir öğretmen özel okullarda bazı derslere daha fazla ağırlık verildiğini belirtmiştir. Konu içeriği bakımında fark olmadığını düşünen öğretmenlerden, Ö2 "Biz Milli Eğitim müfredatını uyguluyoruz. Bu sebeple bir farklıık yok. Programı günü gününe uyguluyoruz. Ancak farklı kaynaklar kullanıyoruz." şeklinde görüş belirtirken Ö6’nın görüşü "Bir farklılı yok Milli Eğitim'in verdiği kılavuz kitaplara ve programa aynen uyarak ders işliyoruz. Veli isterse yardımcı kaynak alıyor." şeklindedir. Özel okul ile devlet okulu arasında öğretim programının içerik boyutunda farklılık olmadığını belirten öğretmenler işleniş bakımından özel okulda kaynak kitap takviyesinin olduğunu belirtmişlerdir. Örneğin kaynak kitapla ilgili Ö8 görüşünü"Müfredata göre konu ve içerikleri işliyoruz. Fakat özel okullarda daha ileri seviye uygulanabiliyor. Daha fazla kaynak kullanabiliyoruz. Devlet okulunda kaynak kullanmak yasak." şeklinde ifade ederken, Ö3 görüşünü "Özel okulda da zaten Milli Eğitim müfredatını uyguluyoruz. Ders kitaplarımız da devletin verdiği kitaplar. Ancak farklı kaynak kitaplar kullanıyoruz." şeklinde ifade etmiştir. Hem donanım desteği hem de bazı derslere daha fazla ağırlık verildiğini düşünen Ö7'nin görüşü ise Devlet okulu ile özel okulu kıyaslayacak olursak özel okullar daha donanımlı. Milli eğitimin müfredatina göre daha zengin kaynak imkanıyla aynı programı uyguluyoruz. Sadece ingilizce dersine verilen ağırlık fazla."şeklindedir.

Araştırmanın cevap aradığı ikinci soru kullanılan yöntem ve teknik bakımından devlet okuluna göre özel okullarda farlılık olup olmadığının belirlenmesidir. Bu kapsamda öğretmen görüşlerinde elde edilen bulgular şekil 2 de verilmiştir. 


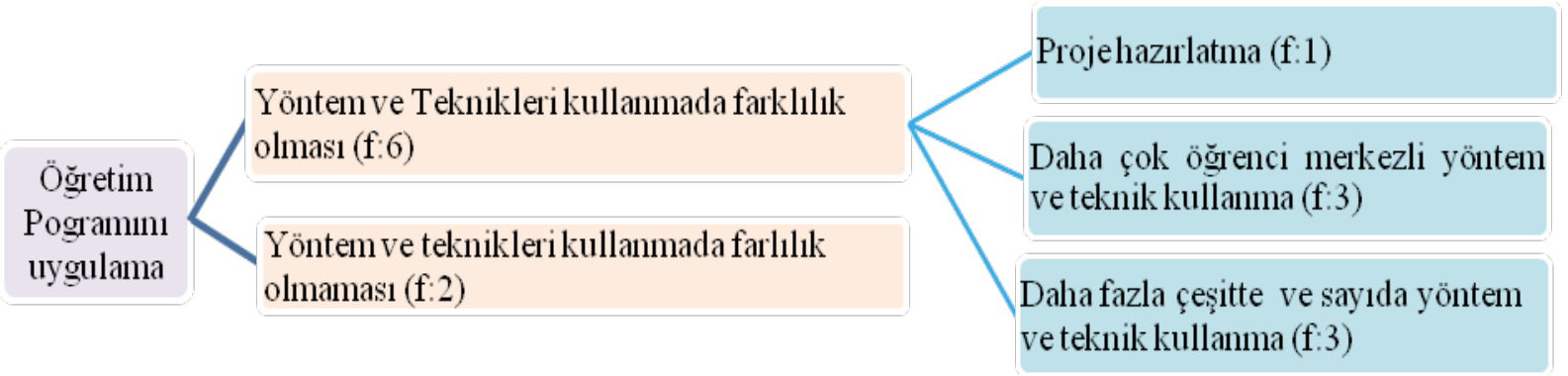

Şekil 2.Öğretmenlerin kullanılan yöntem ve teknik bakımından karşılaştıkları farklılıklar

Kathlımcı öğretmenlerin altısı öğretim programını uygulamada özel okul ve devlet okullarında yöntem ve teknik kullanımı bakımından farklılık olduğunu ifade ederken, iki öğretmen farklılık olmadığını ifade etmiştir. Fark olduğunu vurgulayan öğretmenler bu farklılı̆ın proje hazırlatma, daha çok öğrenci merkezli yöntem ve teknik kullanma, daha fazla çeşitte ve sayıda yöntem ve teknik kullanma şeklinde olduğunu belirtmişlerdir. Örneğin öğrenci merkezli yöntem ve teknik kullandığını belirten Ö8 görüşü Özel okulda daha çok uygulama, yaparak yaşayarak öğrenme teknikleri uyguluyoruz. Öğrenci merkezli eğitim veriyoruz. Fiziki imkânların verdiği rahatılıtan faydalanıyoruz. Anlatım, yaparak yaşayarak, öğrenci merkezli, deney, gezi-gözlem, soru-cevap gibi birçok teknik uyguluyoruz. Zaman daha çok olduğu için konuları daha ayrıntılı işleyebiliyoruz. Özellikle öğrenci merkezli yöntemleri daha çok uygulayabiliyoruz. Drama, canlandırma gibi teknikleri uyguluyoruz şeklindedir. Özel okulda devlet okuluna göre daha fazla yöntem ve teknik kullanıldığını düşünen Ö2, "Özel okullarda istediğimiz yöntem ve teknikleri kullanabiliyoruz. Maddi ve fiziki imkânlar oldukça yeterli. Neredeyse her türlü tekniği uygulayabilecek imkânlarımız mevcut. Zamanımız çok 8 saat eğitim veriyoruz." şeklindeki cümlesiyle görüşünü belirtmiştir. Özel okul ile devlet okulunda yöntem ve teknik açısından bir farklılık olmadığını düşünen öğretmenlerdenÖ1 görüşü "Öğretim yöntem ve teknikleri de aynıdır. Özel okullarda öğrenci mevcudu az olduğundan öğrenciler derslere daha aktif katılmaktadır. Proje hazırlamak ve sunmak daha kolay." şeklinde iken, Ö4 "Özel okullarda öğrenci hazırbulunuşluluğu ve veli ilgisi daha fazla. Öğretim yöntem ve teknikleri bakımından farklı uygulama yapmıyoruz. Fakat öğrencilerle daha fazla vakit geçirdiğimiz için daha faydalı olabiliyoruz." şeklindedir.

Araştırmanın cevap aradığı üçüncü soru kullanılan ölçme ve değerlendirme teknikleri bakımından devlet okuluna göre özel okullarda farlııı olup olmadığııın belirlenmesidir. Bu kapsamda öğretmen görüşlerinde elde edilen bulgular şekil 3'de verilmiştir.

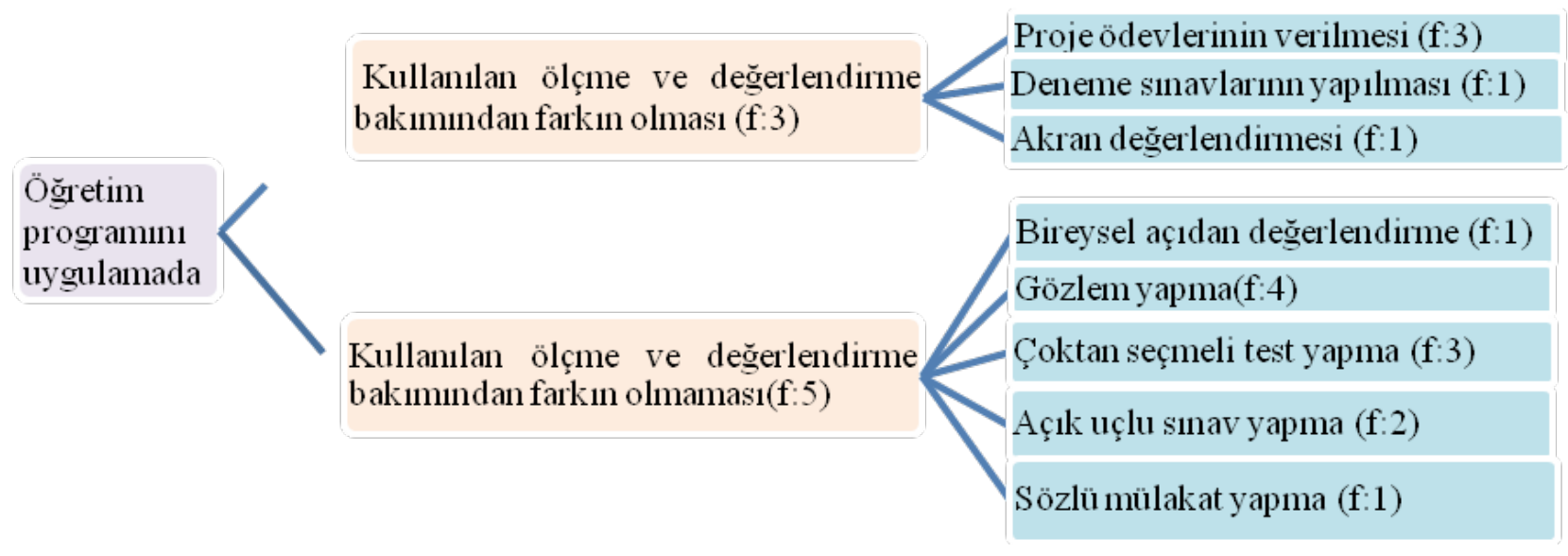

\section{Şekil 3.Öğretmenlerin kullanılan ölçme ve değerlendirme bakımından karşılaşttkları farklıııklar}

Katılımcı öğretmenlerin beşi kullanılan ölçme değerlendirme bakımından özel okullarla devlet okulları arasında farklılık olmadığını belirtirken, üç öğretmen farklılı̆ın olduğunu belirtmişlerdir. Özel okulda uygulanan ölçme ve değerlendirme tekniklerinin devlet okuluna göre farklılık gösterdiğini düşünen öğretmenler farklı uygulama olarak proje ödevleri, akran değerlendirmesi ve deneme sınavları yaptıklarını belirtmişlerdir. Yapılan farklı uygulamalara ilişkin olarak Ö8'in görüşü "Daha fazla deneme yapıyoruz. Çocukların birbirlerini değerlendirmelerini sağlayacak etkinlikler yapıyoruz. Proje ve araştırma ödevlerinin sonuçlarını değerlendirmeye kattyoruz."şeklinde iken, Ö4'ün görüşü “Proje ödevi verip değerlendirme sürecine katyoruz."şeklindedir. Ölçme ve değerlendirme açısından özel okul ile devlet okulu arasında bir farklııı̆ın olmadığı düşünün öğretmenler devlet okulunda uyguladıkları ölçme ve değerlendirme tekniklerini özel okulda da uyguladıklarını vurgulamışlardır. Bunların bireysel açıdan değerlendirme, gözlem yapma,

| Kastamonu Eğitim Dergisi, 27(4), 2019| 
çoktan seçmeli ve açık uçlu sınavlar olduğunu ifade etmişlerdir. Örneğin konuya ilişkin olarak Ö6’nın görüşü “Gözlem ve derse katılım, çocukların gösterdiği ders içi performanslar, her temanın sonucunda birkaç soruluk değerlendirmeler yapıyoruz. Kazanımı ölçüyoruz. Eksiklikleri tekrar pekiştirecek çalışmalar yapıyoruz. ilkokulda branş öğretmenleri de derse giriyor kendi ölçme değerlendirmelerini yapıyorlar." şeklinde iken,Ö3'üngörüşü "Devlet okulundaki gibi uygulama, gözlem, test, açık uçlu sorular, karşılaştırma, eşleştirme gibi soru tipleriyle değerlendirme yapıyoruz." şeklindedir. Ö5 sözlü mülakat yaptı̆ını "Sözlü mülakat, yazılı sınav, test, proje ve performans ödevleri verilerek değerlendirme yapaktayız. Araştırma görevleri veriyoruz." cümlesiyle,Ö7 gözlem yaptğını "Öğrencilere öncelikle test, açık uçlu değerlendirme soruları uyguluyoruz bunun dışında sınıf içi ve sınıf dışı gözlemlerimizle çocuğa not veriyoruz.", cümlesiyle, Ö1 bireysel değerlendirme yaptı̆ını"Bireysel olarak ölçme ve değerlendirme farklı bir uygulama yapmıyorum. Öğrencilerin bireysel durumlarına göre değerlendirme yapıyorum."şeklindeki cümlesiyle ifade etmiştir.

Araştırmanın cevap aradığı dördüncü soru öğretim programın uygulanmasında farklılığın oluşmasına neden olan veli, öğrenci, okulun fiziki donanımı ve yönetiminin etkisinin neler olduğunu belirlemektir. Bu kapsamda öğretmen görüşlerinde elde edilen bulgular şekil 4'de verilmiştir.

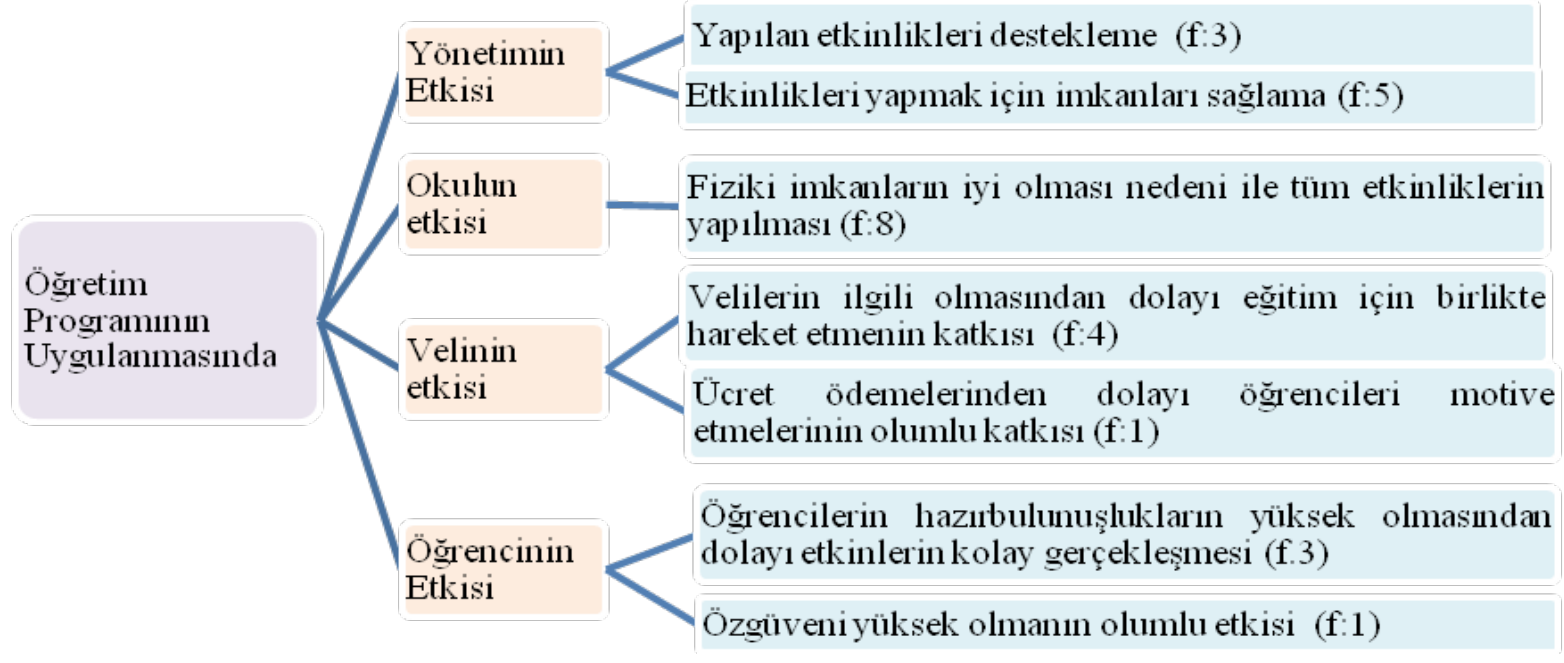

\section{Şekil 4. Öğretmenlerin öğretim programını uygulamasına etki eden faktörler.}

Şekil 4 incelendiğinde özel okulda öğretim programını uygulanmasında yöneticilerin, okulun, velinin ve öğrencinin etkisinin olduğu görülmektedir. Yönetimin etkisini üç öğretmen yapılan etkinlikleri destekleme, beş öğretmen etkinlikleri yapmak için imkânlar sağlama şeklinde olduğunu belirtmişlerdir. Öğretim programının uygulanmasına okul yönetiminin etkisini Ö3, "Yönetim de eğitime yönelik her türlü imkânı sağlamakta." cümlesiyle ifade ederken, Ö8 Okul yönetimi yaptığımız çalışmalara daha çok destek vermekte." şeklindeki cümlesiyle ifade etmiştir. Okulun etkisini katlımcı öğretmenlerin tamamı özel okuldaki imkânlardan dolayı öğretim programı uygulamalarının devlet okullarına göre daha etkili uygulandığını belirtmişlerdir. Örneğin okulun fiziki imkânlarının olumlu etkisine ilişkin olarak görüşünü Ö3 "Okulun fiziki şartları da bize kolaylık sağlıyor. Branş derslerinin uygulanabileceği uygun ortamlar var" şeklinde ifade ederken, Ö5 görüşünü "Okulumuzda her türlü etkinliği yapabileceğimiz konferans salonu, spor salonu, laboratuarlar, futbol, tenis, basketbol sahaları var. Ayrıca okçuluk, satranç ve müzik gibi farklı etkinlikler için de imkânlar mevcut. Bu imkânlar sayesinde eğitimin olumlu katkısı artiyor şeklinde ifade etmiştir. Öğretim programına velinin etkisini ise Ö4, "Veliler ilgili eğitim için gerekli iletişimi sağlayabiliyoruz. Aylık düzenli görüşmelerimiz var. Velilerimiz okulumuzun bir aile yapısında olduğunu söylüyorlar." şeklide ifade ederken, Ö7 "Velilerimizin bir kısmı çocuklarına çok ilgililer, destekçilerimiz olarak arkamızdalar" şeklinde ifade etmiştir. Ö2 velinin motivasyonuna yönelik görüşünü "Veliler de ücret ödedikleri için öğrencinin motivasyonuna katkıda bulunuyorlar şeklinde ifade etmiştir. Öğrencinin özgüvenin ve hazırbulunuşluk düzeyeninde öğretim programının uygulamasına etki ettiğini kathlımcı öğretmenler vurgulamışlardır. Öğrencinin hazırbulunuşluk düzeyinin öğretim programın uygulanmasına etkisini Ö7, Çocuklar devlete göre daha hazır, fiziki olarak gelişmiş, her türlü ihtiyaçları karşılanıyor ve derse hazır geliyorlar.” şeklinde cümlesiyle açıklarken, Ö3 "Öğrenciler kreş ve anaokulu temeli almış. Hazır olarak geliyorlar." şeklindeki cümlesiyle açıklamıştır.

\section{Tartışma ve Sonuç}

Bu araştırmanın sonucunda özel okulda çalışan sınıf öğretmenleri devlet okullarında uygulanan öğretim programının içeriğine uygun, başka bir deyişle derslerde aynı konu başıklarını işlediklerini vurgulamışlardır. Ancak konuların 
işlenmesinde, devlet okullarından farklı olarak, konuya daha çok zaman ayırdıklarını, yardımcı kaynak kullandıklarını, bazı derslere daha çok ağırlık verdiklerini belirtmişlerdir. Özel okulda sınıf öğretmenlerinin program içeriğine bağı kalmasının nedeni, Bümen, vd. (2014) tarafindan, tasarlanan programın öğretmen/paydaşlar tarafindan aslına sadık kalınarak uygulanması şeklinde tanımlanan öğretim programına bağlıık kavramıyla açıklanabileceği gibi, öğretmenlerin MEB tarafindan denetlenme endişesi taşımasından da (MEB, 2016; Memduhoğlu, 2008; Özdemir ve Tüysüz, 2017) kaynaklanabilir. Özel okulda çalışan öğretmenlerin öğretim programındaki konu içeriğine sadık kalmasının diğer bir nedeni velilerin akademik başarı beklentisi içinde olmalarından (Çelikten, 2010) kaynaklanabilir. Türkiye'de akademik başarının göstergesi öğrencilerin sınavlarda aldıkları bunlara bağlı olarak değişmektedir. Merkezi sınavlarda çıkan sorular öğretim programında yer alan kazanımları ölçmeye yönelik hazırlanmaktadır. Bu durum akademik başarıya odaklanan öğretmeni öğretim programının içeriğine bağlı kalmasını sağlayabilir. Merkezi sınavlarda öğrencilerin daha başarılı olma isteğinin getirdiği rekabetçi anlayış nedeni ile özel okulda ek kaynak aldırma konusunda devlet okulunda olduğu gibi herhangi bir sınırlamanın olmamasının avantajı, bu araştırmanın sonucu da olan öğretmenlerin ek kaynak aldırmaları öğretmenlerin öğrencilerinin sınav başarısı ile ilgili endişe taşıdıklarını destekler niteliktedir. Ayrıca bu araştırmanın bir diğer sonucu olan öğretmenlerin İngilizce gibi bazı derslere daha çok ağırlık vermelerinin sebebi veli beklentilerini karşılama çabasından kaynaklanabilir. Alan yazında yapılan çalışmalarda yabancı dil öğretilmesi velilerin özel okulları tercih etme sebepleri arasında yer almaktadır (Açıkalın, 1989; Çelikten ve Parlar, 2006).

Araştırmanın diğer bir sonucu ise öğretim ilke ve yöntemlerinin uygulama açısından özel okul ile devlet okulu arasında farkın olmasıdır. Bu farkın çıkmasında özel okul ile remi okuldaki eğitim ortamının farklı olmasından kaynaklanmış olabilir. Pehlivan’ın (2004) da vurguladığı gibi bir okulun sahip olduğu donanım, araç-gereç durumu ve fiziki özellikleri öğretim programlarının uygulamasını etkileyen önemli bir faktördür. Alkan, Deryakulu ve Şimşek (1995) eğitim ortamını oluşturan öğelerin fiziki mekân, öğrenme araç ve gereçleri, personel, eğitsel çevre, özel düzenlemeler olduğunu belirtmektedir. Eğitim ortamı bakımından özel okulların daha avantajlı bir konumda olduğu bunun ise farklı öğretim yöntemleri kullanmayı kolaylaştırdığı söylenebilir. Öğretmenlerin sahip olması gereken becerilerden biri ise eğitim ortamına uygun yöntem ve teknikleri seçebilme ve kullana bilme becerisi olduğu araştırmalarda belirtilmektedir. (Tan, Kayabaşı ve Erdoğan, 2003; Titiz, 2005; Yıldırım, 2000). Bu araştırmada öğretim ilke ve yöntemlerinin uygulama açısından özel okul ile devlet okulu arasında farkın çıkması öğretmenlerin öğretim ortamına uygun yöntem ve teknik seçebilme becerisine sahip olduklarını da gösterebilir. Öğretim ilke ve yöntemlerinin uygulama açısından özel okul ile devlet okulu arasında farkın olmasının diğer bir sebebi ise velilerin bu yöndeki beklentileri olabilir. Nitekim Nartgün ve Kaya'nın (2015) yapmış oldukları çalışmada, velilerin özel okullarda çalışan öğretmenlerden sınıf içinde farklı yöntem ve teknikler kullanarak bireysel farklııkları ortaya çıkaracak çalışmalar yapmalarını beklemektedirler sonucu, velilerin bu yöndeki beklentilerinin karşılanması görüşünü destekler niteliktedir.

Bu araştrrmada özel okul ile devlet okullarında kullanılan ölçme ve değerlendirme teknikleri açsısından önemli ölçüde farkın olmadığı sonucuna ulaşılmıştr. Her iki okulda öğretmenlerin geleneksel ölçme ve değerlendirme teknikleri olan gözlem, test, yazlı yoklama tekniklerini kullandıkları görülmektedir. Diğer bir ifade ile öğretmenler yapılandırmacı anlayışa uygun ölçme ve değerlendirme tekniklerini kullanmadıkları söylenebilir. Bunun nedeni öğretmenlerin alternatif ölçme ve değerlendirme araçlarını ve onların uygulamalarının nasıl yapıldığına ilişkin yeterli bilgi ve beceriye sahip olmamaları, (Anıl ve Acar, 2007; Gelbal ve Kelecioğlu 2007; Okur ve Azar, 2011; Sağlam Arslan, Kaymakçı Devecioğlu ve Arslan, 2009; Yayla, 2011), öğretmenlerin ölçme-değerlendirmeyle ilgili sahip oldukları kültürü değiştirilememesi (Cansız Aktaş, 2008) olabilir. Araştırmada öğretmenler özel okulda devlet okulundan farklı olarak deneme sınavlarını bir ölçme araçları olarak kullandıkları belirtilmişlerdir. Öğretmenlerin özel okulda deneme sınavlarını bir ölçme aracı olarak kullanmalarında merkezi sınavlara hazırlığın bir yansıması olarak değerlendirilebilir.

Özel okulda öğretim programının uygulanmasına yöneticilerin, okulun fiziki alt yapısının, velinin ve öğrencinin etkisi olduğu araştırmanın diğer bir sonucudur. Araştırmanın bu sonucunu alanyazında yapılan çalışmalara desteklemektedir (Bay, vd., 2017; Bümen, vd., 2014). Okul yönetimleri yapılan etkinlikleri destekleme ve öğretmenlerin etkinlikleri yapması için imkânlar sunma şeklinde öğretim programı uygulamalarına katkı sunmuşlardır. Dağdeler ve Arseven (2015) yapttğı çalışmada okul yöneticisinin öğretim programını uygulamada uygun öğrenme ortamını sağlama; öğretmen, öğrenci ve veli arasında eşgüdümü sağlama gibi sorumlulukları olduğunu söylemektedir. Devlet okullarından farklı olarak özel okullarda okul yönetimi, öğretmenlerin uygulamalarından direk sorumlu olduğundan, öğretmenlerin uygulamaları sonucunda meydana gelen başarı ve başarısızlıklarından tüm kurum etkilendiğinden, ticari kaygı taşınmasından, özel okul yöneticileri devlet okulları yöneticilerine göre öğretmenleri daha çok desteklemiş olabilirler. Bu araştırmada öğretmenler özel okulun fiziki alt yapısının, devlet okullarına göre daha iyi olmasından dolayı öğretim programını daha etkin uyguladıklarını belirtmişlerdir. Alanyazında yapılan çalışmada devlet okullarında görev yapan öğretmenlerin fiziki alt yapıdaki eksiklikler yüzünden öğretim programını tam anlamıyla uygulayamadıklarını belirtmesi (Doğan, 2010; Geçer ve

| Kastamonu Eğitim Dergisi, 27(4), 2019| 
Özel, 2012; Karaman ve Karaman, 2016; Yangın ve Dindar, 2007), bu araştırmanın öğretim programının uygulanmasına okulun fiziki donanımın etkisi sonucunu destekler niteliktedir. Velilerin ilgili olması ve ücret ödedikleri için öğrencileri motive etmeleri öğretim programı uygulamalarına olumlu katkı sağladığı sonucuna ulaşımıştır. Çetin (2017) yaptığı çalışmanın sonucu olan velilerin ücret ödediğinde öğrencilerin daha disipline olmuş olması ve dersi daha etkin dinlemesi, bu araştırmanın velilerin öğretim programı uygulamasına katkısı sonucunu destekler niteliktedir. Aynı zamanda özel okulda kaliteli eğitimin gerçekleşmesi ve istenilen başarının yakalanmasında veli ve öğrenci beklentilerinin öğretim programına yansıması gerekebilir. Çünkü hizmeti alan kesim veliler ile öğrencilerdir ve özel okullar bu beklentilere cevap verdikleri zaman velilerin ve öğrencilerin memnuniyetleri artmaktadır (Gürbüz, 2005; Nartgün ve Kaya, 2015). Velilerin beklentileri karşılama ve onları memnun etme adına özel okul yönetimi velilerin görüş ve düşünceleri daha fazla önem vermesi öğretim programının uygulanmasında velilinin etkisinin görülmesinin sebebi olarak da yorumlanabilir. Diğer taraftan velilerin öğretim programı uygulamasına etkisi ise özel okulda veli, öğrenci ve okul arasında kurulan etkili iletişim mekanizmasının kurulmasındanda kaynaklanabilir. Bu araştırmada öğrencilerin hazırlık bulunuşlarının ve özgüvenlerinin yüksek olmasının öğretim programı uygulamalarına etkisi olduğu sonucu dikkat çekicidir. Bu araştırmanın sonucuna benzer şekilde Bümen, vd. (2014) yaptı̆̆ı çalışmada öğretim programının uygulanmasını etkileyen faktör arasında öğrenci özelliklerinin, sosyal, ekonomik, kültürel özelliklerin olduğu belirtilmektedir. Özel okul velilerinin imkânlarından dolayı öğrencilerin; beslenme, giyinme, uyuma gibi temel ihtiyaçların karşılanarak okula gönderilmesi fiziksel olarak hazırbulunuşluğunu artırabilir. Öğrencilerin kreş ve anaokuluna gitmesinden dolayı öğrencilerin akademik hazırbulunuşluğu artabilir, okul ortamına uyumu daha kolay olabilir. Tüm bu nedenlerden dolayı öğretmen öğretim programını daha etkin uygulayabilir.

\section{5. Öneriler}

Bu araştırmanın sonucunda aşağıdaki öneriler geliştirilmiştir:

- Öğretim programı uygulamasının daha etkin bir şekilde yürütülmesi için devlet okullarının fiziki alt yapısının iyileştirmesi sağlanmalıdır.

- Ölçme ve değerlendirme süreci bakımından sınıf öğretmenleri gerek devlet okulunda gerekse özel okulda geleneksel ölçme ve değerlendirme teknikleri kullandıklarına yönelik sonuç göz önünde bulundurulduğunda, bunun nedenleri ve bu durumu gidermeye yönelik çalışmalar yapılabilir.

- Öğretim programının uygulanmasında en önemli faktörlerden olan öğrencilerin hazırbulunuşluk düzeyleri artrılmalıdır.

- Bu çalışma nitel araştırma deseni ile yürütülmüştür, yapılacak başkaca çalışmalarda daha genişörneklem grubu ile nicel çalışmalar yapılabilir.

- Velilerin ve öğrencilerin programa etkisinin öğretmen tarafindan nasıl algılandığı derinlemesine yapılacak araştırmalar ile açığa çıkartılabilir.

\section{Kaynakça}

Acar, H. (2007). Yeni ilköğretim programlarının öğretmen görüşlerine dayalı olarak değerlendirilmesi. Yayımlanmamış Yüksek Lisans Tezi, Eskişehir Osmangazi Üniversitesi, Eskişehir.

Açıkalın, A. (1989). Özel ve devlet liselerinde veli beklentilerinin örgütsel ve yönetsel boyutları. Hacettepe Üniversitesi Eğitim Fakültesi Dergisi, 4, 85-91

Akın, F., Şimşek, O., Erdem ve F. (2007). Toplumsal aktörlere göre eğitim sorunlarına bakış, Ankara:Türk Eğitim Sen Yayınları

Alkan, C., Deryakulu, D. ve Şimşek, N. (1995). Eğitim teknolojisine giriş: disiplin, süreç, ürün. Ankara: Önder Matbaacılık.

Anıl, D. ve Acar, M. (2008). Sınıf öğretmenlerinin ölçme değerlendirme sürecinde karşılaştkkları sorunlara ilişkin görüşleri. Yüzüncü yıl Üniversitesi Eğitim Fakültesi Dergisi, 5(11), 44- 66.

Aydemir, H. (2011). ilköğretim 7. Sınıf sosyal bilgiler öğretim programı etkinliklerinin uygulamadaki etkililiğinin değerlendirilmesi. Yayımlanmamış Doktora Tezi. Fırat Üniversitesi, Elazığ

Aykaç, N. (2007). illköğretim programında yer alan etkinliklerin öğretmen görüşleri doğrultusunda değerlendirilmesi (sinop ili örneği). Ahi Evran Üniversitesi Kırşehir Eğitim Fakültesi Dergisi (KEFAD), 8(2):19-35

Aykaç, N. ve Ulubey, Ö. (2012). Öğretmen adaylarının ilköğretim programının uygulanma düzeyine ilişkin görüşleri Ankara University, Journal of Faculty of Educational Sciences. 45(1) 63-82.

Bal, A.P., (2008). Yeni ilköğretim matematik öğretim programının öğretmen görüşleri açısından değerlendirilmesi. Ç.Ü. Sosyal Bilimler Enstitüsü Dergisi, $17(1), 53-68$.

Bay, E., Kahramanoğlu, R., Döş, B. ve Özpolat, E.T. (2017). Programa bağlılığı etkileyen faktörlerin analizi. Mehmet Akif Ersoy Üniversitesi Eğitim Fakültesi Dergisi. 43. 110-137.

| Kastamonu Eğitim Dergisi, 27(4), 2019| 
Berberoğlu, G. Ve Kalender, İ. (2005). Öğrenci başarısının yıllara, okul türlerine, bölgelere göre incelenmesi: öss ve pısa analizi, Eğitim Bilimleri ve Uygulama, 4 (7), 21-35.

Bümen, N. T., Çakar, E. Ve Yıldız, D. G. (2014). Türkiye'de öğretim programına bağlııı ve bağlılığı etkileyen etkenler, Kuram ve Uygulamada Eğitim Bilimleri, 14(1), 203-228.

Bütün, M. ve Gültepe T., (2016). Ortaokul matematik dersi öğretim programının uygulamaya yansıtılması ile ilgili öğretmen görüşleri, Eğitim ve Öğretim Araştırmaları Dergisi, 5, 80-89.

Cansız Aktaş, M. (2008). Öğretmenlerin yeni ortaöğretim matematik öğretim programının ölçme ve değerlendirme boyutuna bakışlarının incelenmesi. Yayınlanmamış Doktora Tezi, Karadeniz Teknik Üniversitesi, Trabzon.

Creswell, J. W. (2015). Nitel araştırma yöntemleri (M. Bütün ve S. B. Demir, Çev.) (2. bs.). Ankara: Siyasal Kitabevi. [Orijinal baskı 2013].

Çelikten, B. (2010). Özel okul velilerinin okul tercihlerini etkileyen faktörler. Yayımlanmamış Yüksek Lisans Tezi, Yeditepe Üniversitesi, İstanbul.

Çepni, S. (2007). Araştırma ve proje çalışmalarına giriş. (Genişletilmiş 3. Baskı), Trabzon: Celepler Matbaacılık.

Çobanoğlu, A. (2011). Resmi ve özel ilköğretim okullarının okul imajının öğretmen ve veli görüşlerine göre değerlendirilmesi. Yayınlanmış Yüksek Lisans Tezi. Marmara Üniversitesi, İstanbul

Dağdeler, í. ve Arseven A. (2015). ílkokul öğretim programlarının uygulanmasında okul yöneticilerinin görev ve sorumluluklarına ilişkin okul yöneticilerinin ve öğretmenlerin görüşleri, International Journal of Social Science, 33, 185-205

Demirel, Ö. (2012). Eğitimde program geliştirme. Ankara:Pegem akademi

Dikbaş i (2008).Veli beklentileri ve karşılanma düzeyleri, özel vakıf okulları örneği. Yayınlanmamış Yüksek Lisans Tezi. Yeditepe Üniversitesi, İstanbul.

Dinler, A., ve Subaşı, B. (2003). Dünyada ve Türkiye'de özel okullar. İstanbul: İstanbul Ticaret Odası Yayınları.

Doğan, Y. (2010). Fen ve teknoloji dersi programının uygulanması sürecinde karşılaşılan sorunlar. Yüzüncü Yıl Üniversitesi Eğitim Fakültesi Dergisi, 7(1), 86-106.

Ensari, H. (2002). Eğitimde kalite arayışları ve özel okullar paneli. Özel Okullar ve Eğitimde Kalite. (Ed: İ. Erdoğan) İstanbul: Özel Okullar Derneği Yayını.

Ercan, O.(2011). Kimya dersi yeni öğretim programının uygulanmasına ilişkin öğretmen görüşleri, TÜRK Fen Eğitimi Dergisi 8(4)), $193-209$.

Erdoğan, İ. (2005). Yeni bir binyıla doğru türk eğitim sistemi. 4.Baskı, İstanbul: Sistem Yayıncılık

Eyüpoğlu, R. (2002). Genel değerlendirme. Özel okullar ve eğitimde kalite (Ed: İ. Erdoğan) İstanbul: Özel Okullar Derneği Yayını.

Fettahoğlu, B. (2011). 7. sınıf sosyal bilgiler öğretim programının öğretmen görüşlerine göre değerlendirilmesi-nitel bir çalışma (Gümüşhane İli Örneği).Yayımlanmamış Yüksek Lisans Tezi. Erzincan Üniversitesi, Erzincan

Geçer, A. Ve Özel, R. (2012). illköğretim fen ve teknoloji dersi öğretmenlerinin öğrenme-öğretme sürecinde yaşadıkları sorunlar. Kuram ve Uygulamada Eğitim Bilimleri, 12(3), 1-26.

Gelbal, S.ve Kelecioğlu, H. (2007). Öğretmenlerin ölçme değerlendirme yöntemleri hakkında yeterlilik algıları ve karşılaştikları sorunlar. Hacettepe Üniversitesi Eğitim Fakültesi Dergisi, 33, 135-145.

Görgen, i. (2012). Program geliştirmede temel kavramlar. Hasan Şeker (Ed.), Eğitimde Program Geliştirme İçinde (s.1-18). Ankara: Anı Yayıncilık.

Gürbüz, E. (2005). Devlet ve özel ilköğretim okullarında hizmet kalitesinin karşılaştırılmasına ilişkin bir araştırma, Gazi Üniversitesi iktisadi ve Idari Bilimler Fakültesi Dergisi, 7(1), 97-119

Gwimbi, E. M.,Monk, M. (2003). Study of classroom practice and classroom contexts amongst senior high school biology teachers in harare, zimbabwe. Science Education, 87, 207-223.

Han, Ç. (2013). Öğretmenlerin işlevsel paradigmaları ve eğitim reformu. Trakya Üniversitesi Eğitim Fakültesi Dergisi, 3(1):59-79.

Kara, K., Karakoç, B., Yıldırım, İ. ve Bay E. (2017). Sekizinci sınıf matematik öğretiminde teori ve uygulama bağlamında program uyumluluğunun incelenmesi, Harran Education Journal, 2(1), 26-40.

Karaman, P.ve Karaman, A. (2016). Fen bilimleri öğretmenlerinin yenilenen fen bilimleri öğretim programına yönelik görüşleri. Journal of Education Faculty, 18(1), 243-269.

Kızıltepe Z. (2015). Içerik analizi, Seggie, N.F ve Bayyurt (Ed.) Nitel araştırma yöntem, teknik, analiz ve yaklaşımları; Ankara: Anı yayınclık. Küçükahmet, L. (1997). Eğitim programları ve öğretim. Ankara: Gazi Kitapevi.

Lincoln, Y.S. \& Guba, E.G. (1985). Naturalistic inquiry. California: SAGE.

MEB (2016a). Milli Eğitim Bakanlığı, 5580 Sayılı Özel Öğretim Kurumları Kanunu, http://www.mevzuat.gov.tr/ Mevzuat Metin/1.5.5580. pdf, erişim tarihi: 18.12.2017.

Memduhoğlu, H. B. (2008). Türk eğitim sisteminin genel yapısı (Amaçlar, Temel Illkeler ve Okul Sistemi). Türk Eğtim Sistemi ve Okul Yönetimi (Ed: H.B. Memduhoğlu ve K. Yılmaz), Ankara: Pegem A.

Mermertaş, M. F. (2014). Özel eğitim kurumlarının tercih nedenleri ile öğrencilerin memnuniyeti arasındaki ilişki: Şırnak örneği. Yayınlanmış Yüksek Lisans Tezi. Türk Hava Kurumu Üniversitesi, Sosyal Bilimler Enstitüsü 
Miles, B. M. \& Huberman A. M., (1994). Qualitative data analysis: an expanded source book. 2nd ed. California, USA: Sage Publications, $\mathrm{p}: 27$.

Nartgün, Ş. ve Kaya, A. (2016). Özel okul velilerinin beklentileri doğrultusunda okul imajı oluşturma. Journal of Research in Education and Teaching, 5(2), 154-167.

Okur, M. ve Azar, A. (2011). Fen ve teknoloji dersinde kullanılan alternatif ölçme tekniklerine ilişkin öğretmen görüşleri. Kastamonu Eğitim Dergisi, 19(2), 387- 400

Özdemir A. ve Tüysüz F.(2017) Özel okul yattrımları için türkiye'deki 81 ilin çok kriterli karar verme yöntemleri ile stratejik analizi. Marmara Üniversitesi Atatürk Eğitim Fakültesi Eğitim Bilimleri Dergisi 45, 93-114

Öztürk, E.ve Demircioğlu, H. (2002). Lise biyoloji öğretim programı uygulanmasında öğretmen rolü. V. Ulusal Fen Bilimleri ve Matematik Eğitimi Kongresi (16-18 Eylül), Ankara, Bildiriler, I, 122-128

Öztürk, í. H. (2012). Öğretimin planlanmasında öğretmenin rolü ve özerkliği: ortaöğretim tarih öğretmenlerinin yıllık plan hazırlama ve uygulama örneği. Kuram ve Uygulamada Eğitim Bilimleri, 12, 271-299

Öztürk Akar, E. (2005). Lise biyoloji dersi öğretim programının uygulanmasında okul düzeyinde görülen farklııklar. Eğitim Bilimleri ve Uygulama, 4(7), 51-67.

Parlar, H. (2006). Velilerin özel okul tercihlerini etkileyen faktörler ve özel okulların durumu: Kahramanmaraş örneği. Yayınlanmamış Yüksek Lisans Tezi, Yeditepe Üniversitesi, İstanbul

Patton, M. Q. (2014). Nitel araştırma ve değerlendirme yöntemleri (M. Bütün ve S. B. Demir, Çev.). Ankara: Pegem Akademi.

Pehlivan, K. B. (2004). Sınıf öğretmeni adaylarının öğretmenlik mesleğine yönelik tutumları ve okul tutumları arasındaki ilişki. Eğitim Araştirmaları Dergisi, 14, 211-218.

Sağlam Arslan, A., Devecioğlu Kaymakçı, Y. ve Arslan, S. (2009). Alternatif ölçme değerlendirme tekniklerinde karşılaşılan problemler: fen ve teknoloji öğretmeleri örneği. On Dokuz Mayıs Üniversitesi Eğitim Fakültesi Dergisi, 28, 1-12.

Tan, Ş., Kayabaşı, Y. ve Erdoğan, A. (2003). Öğretimi planlama ve değerlendirme. Ankara: Anı yayıncılık.

Tavşancıl, E. ve Aslan E. (2001). İçerik Analizi ve Uygulama Örnekleri. Epsilon Yayınları: İstanbul.

Tekbıyık, A. Ve Akdeniz, A. R. (2008). illköğretim fen ve teknoloji dersi öğretim programını kabullenmeye ve uygulamaya yönelik öğretmen görüşleri. Necatibey Eğitim Fakültesi Elektronik Fen ve Matematik Eğitimi Dergisi, 2(2):23-37.

Titiz, O. (2005). Yeni öğretim sistemi. İstanbul: Zambak yayınları

Uygun, S. (2003). Türkiye'de dünden bugüne özel okullara bir bakış (Gelişim ve Etkileri). Ankara University, Journal of Faculty of Educational Sciences, 36. 1-2.

Uysal, B.S., (2017). Velilerin özel okul tercih nedenlerinin incelenmesi (İstanbul Örneği). Yayınlanmamış Yüksek Lisans Tezi. İstanbul

Yangın, S., Dindar, H. (2007). Ilköğretim fen ve teknoloji programındaki değişimin öğretmenlere yansımaları. Hacettepe Üniversitesi Eğitim Fakültesi Dergisi, 33(33).

Yaman, H. (2009). Illköğretim türkçe dersi programının kalabalık sınıflarda uygulanabilirliğine ilişkin öğretmen görüşleri. Kuram ve Uygulamada Eğitim Bilimleri 9 (1), 329-359.

Yaşaroğlu, C. Ve Manav, F .(2015.) Öğretim programına bağılık ölçeği: geçerlik ve güvenirlik çalışması. Uluslararası Eğitim Bilimleri Dergisi 2, (4), 247-258

Yayla, G. (2011). Fen ve teknoloji öğretmenlerinin tecrübeleriyle alternatif ölçme değerlendirme yaklaşımlarına yönelik öz yeterlilikleri arasındaki ilişki. International Conference on New Trends in Education and Theirlmplications, Siyasal Kitabevi, 879-883.

Yıldııım, A. ve Şimşek, H. (2013). Sosyal bilimlerde nitel araştırma yöntemleri. Seçkin Yayıncılık.

Yıldıım, V. (2000). Illköğretim okulu 5. sınıf öğretmenlerinin öğretim yöntemleri konusundaki görüşleri. Yayınlanmamış Yüksek Lisans Tezi. Fırat Üniversitesi Sosyal Bilimler Enstitüsü, Elazığ 